\title{
The Effects of Rifampicin on Neuronal Survival
}

\author{
Rifampisinin Nöronal Sağkalım Üzerine Etkileri
}

\author{
ilknur Yurtsever ${ }^{1}$ (D) Ebru Emekli Alturfan² \\ ${ }^{1}$ Regenerative and Restorative Medicine Research Center, İstanbul Medipol University, İstanbul, Turkey \\ ${ }^{2}$ Department of Biochemistry, Marmara University School of Dentistry, İstanbul, Turkey
}

Cite this article as: Yurtsever I, Emekli Alturfan E. The Effects of Rifampicin on Neuronal Survival. Experimed 2019; 9(3): 138-42.

\begin{abstract}
Neurodegenerative diseases are characterized by the formation of insoluble aggregates of misfolded proteins in the central nervous system. The $\beta$-amyloid protein in Alzheimer's disease and a-synuclein formation in Parkinson's disease (PD) may be given as examples. In addition to a-synuclein accumulation in Parkinson's disease, mechanisms such as oxidative stress, dysfunction of mitochondria, inflammation response, and apoptosis are known to be involved in the disease process. Since the mechanisms underlying these diseases are partially known, the drugs developed are intended to slow the disease process rather than cure them. Rifampicin is an antibiotic commonly used in humans and known to easily penetrate into the brain after oral intake. Studies have shown that rifampicin suppresses mitochondrial oxidative stress, eliminates a-synuclein fibrils and inhibits inflammation in in vitro and in vivo disease models. In this study, we reviewed recent studies on the neuronal protection of rifampicin and the effects of rifampicin on the pathophysiological mechanisms of PD.
\end{abstract}

Keywords: Parkinson's disease, rifampicin, a-Synuclein, SUMOylation, inflammation, autophagy

\section{INTRODUCTION}

Although rifampicin is a widely used antibiotic in the treatment of tuberculosis and leprosy, studies have increasingly shown that rifampicin has therapeutic benefits for acute brain injury and chronic neurodegenerative diseases (1-5). Among the neurodegenerative diseases, Parkinson's disease (PD) and Alzheimer's disease are the two major diseases where the therapeutic benefits of rifampicin have been shown. PD is the second most common neurodegeneration disease in the world and is caused by the loss of dopaminergic neurons in the substantia nigra compacta region of the brain. Many pathological mechanisms proposed for PD include mitochondrial dysfunction, increased oxidative stress, protein misfolding-aggregation, apoptosis, inflammatory response and glutaminergic excitotoxicity, and nitrosative stress (6).

\section{öz}

Nörodejeneratif hastalıklar, merkezi sinir siteminde yanlış katlanmış proteinlerin çözünmeyen agregatlarının oluşumu ile karakterizedir. Bunlara örnek olarak; Alzheimer hastalığında $\beta$-amyloid protein ve Parkinson hastalığında $\alpha$-sinüklein oluşumu verilebilir. Parkinson hastalığında a-sinüklein agregasyonuna ek olarak, oksidatif stress, mitokondri fonksiyon bozukluğu, inflamatuvar cevap, apoptoz gibi mekanizmaların hastalık sürecine katılığı bilinmektedir. Bu hastalıkların altında yatan mekanizmalar tam olarak bilinmediği için, hastalığa ilişkin geliştirilen ilaçlar, hastalığı iyileştirmekten çok, hastalığın seyrini yavaşlatma eğilimindedir. Rifampisin insanlar tarafından sıkça kullanılan bir antibiyotiktir ve ağız yoluyla alındıktan sonra beyne kolaylıkla penetre olmaktadır. Rifampisinin in vivo ve in vitro hastalık modellerinde mitokondriyal oksidatif stresi baskıladığı, a-sinüklein fibrillerini ayrıştırdığı, inflamasyonu inhibe ettiğini gösteren çok sayıda çalışma mevcuttur. Biz bu çalışmada, rifampisinin nöronal korunumu üzerine raporlanan çalışmaları ve Parkinson hastalığı'nın patofizyolojik mekanizmaları üzerine rifampisinin etkilerini derledik.

Anahtar Kelimeler: Parkinson hastalığı, rifampisin, a-Sinüklein, SUMOlasyon, inflamasyon, otofaji

There are studies showing that rifampicin significantly increases the viability of neurons in in vitro models of PD (7). However, rifampicin inhibited apoptosis in neurons by activating glucose-regulated protein 78 (GRP78), an endoplasmic reticulum stress marker, and inhibiting the expression of a-synuclein multimers $(8,9)$. There are also studies showing that rifampicin has the ability to suppress inflammation by inhibiting the nuclear transfer of Nf-kB and the release of IL-1 $\beta$, TNF- $\alpha$ and other inflammatory factors in microglia (10). Accordingly, rifampicin has been shown to protect neurons by different mechanisms including its effects on oxidative stress, autophagy, and mitophagy, a-Synuclein aggregation and SUMOylation (Figure 1). Here, we have reviewed recent studies on the effects of rifampicin on the mechanisms involved in the pathophysiology of PD. 


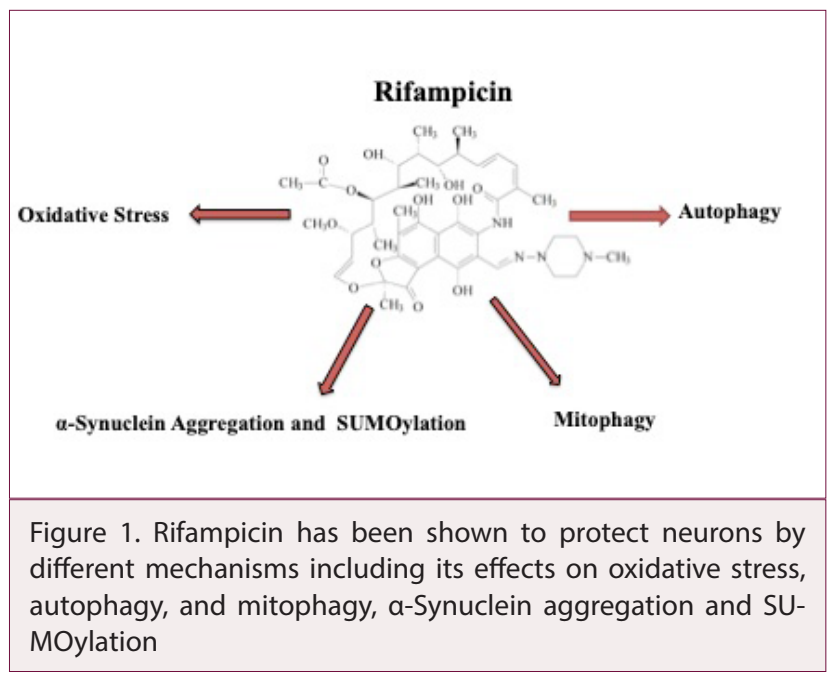

\section{Rifampicin and Oxidative Stress}

Researchers have shown that mitochondrial dysregulation plays an important pathological role in dopamine loss in various PD models $(11,12)$. It is known that PD-causing chemicals, such as rotenone and MPTP, inhibit mitochondrial complex I in dopaminergic neurons, reduce ATP production, and cause increased reactive oxygen species (ROS), as well as oxidative stress (13-16). Mitochondrial dysfunction can result from both increased damage and a reduced ability to repair or clear damaged mitochondria (17).

One of the common ways described in experimental models of neurodegenerative diseases is oxidative/nitrosative stress (OS/NS). This event triggers a series of harmful actions involving the primary formation of reactive oxygen and nitrogen species (ROS/RNS), affecting the structure and function of different biological molecules, leading to specific toxic processes that endanger cell redox status $(18,19)$. Mitochondria have been shown to be the main source of ROS and responsible for oxidative stress-induced cell death in neurodegeneration $(20,21)$.

Being the first-line antituberculosis, rifampicin is recommended by the World Health Organization (WHO). However, hepatotoxicity which is the main limiting factor for eliminating the clinical use of rifampicin is accepted to be the major side effect in the treatment of tuberculosis. Although rifampin alone has low hepatotoxicity it may show additive/synergistic hepatotoxicity when it is used with isoniazid during the treatment of tuberculosis (22). Accordingly, rifampicin has been shown to cause liver damage through the induction of cholestasis, with a serious increase in serum bilirubin levels. As oxidative stress is sometimes related to cholestasis and suggested to have a role in the endocytosis of envelope proteins; rifampicin has also been related to oxidative stress in the liver (23). Moreover, Xu et al. showed that rifampicin decreased multidrug resistance-associated protein 2 levels through the induction of oxidative stress in HepG2 cells (23).
In contrast, rifampicin has been shown to act differently in the neuronal system. It has been shown that rifampicin-treated animals had decreased oxidative stress in the nigrostriatal dopaminergic neuronal pathways and provided neuronal protection (24). As rifampicin has been reported to reduce ROS release and secondary brain injury in Streptococcus pneumoniae meningitis, it can be a potential treatment for the disease (25). In in vitro studies, rifampicin pretreatment protected PC 12 cells against rotenone-induced cell death and inhibited the formation of a-synuclein multimers as well. Qualitative and quantitative analyses showed that rifampicin significantly prevented rotenone-induced apoptosis by relieving mitochondrial oxidative stress (26). As the oxidative process changes mitochondrial respiration and leads to changes in the permeability of the transition pores in the mitochondria of the brain; prevention of oxidative stress by rifampicin may have important functions for the development of new treatment strategies.

\section{Rifampicin and Autophagy}

Mitochondrial dysfunction is related very closely with the pathogenesis of PD. It may be the result of impaired mitochondrial biogenesis, high ROS formation, impaired mitophagy and electron transport chain dysfunction as well as alterations in the dynamics of mitochondrial functions and calcium homeostasis. Neuroinflammation is a mitochondrial and autophagic dysfunction, associated with the pathophysiology of PD. In order to remove damaged proteins and the mitochondria, a very well regulated lysosomal-mediated autophagy pathway is needed. This autophagy pathway integrates various signals including nutrient availability, cellular stress and oxidized proteins and lipids (27).

Rifampicin inhibits the formation of a-synuclein multimers and neuronal apoptosis by the activation of GRP78 via the PERKelF2a-ATF4 pathway $(8,9)$. Furthermore, rifampicin administration is useful for lipopolysaccharide (LPS) -stimulated microglia-damaged neurons by suppressing the nuclear factor kappa $B$ activation, phosphorylation of MAPKs and the toll-like receptor-4 (TLR-4) pathway $(10,28)$.

Studies have shown that inhibition of autophagy, in particular, mitophagy, leads to a reduced degradation of damaged mitochondria and an increased production of ROS (29). Previous studies have shown that pre-administration of rifampicin inhibits neuroinflammation by the suppression of $26 \mathrm{~S}$ protease regulatory subunit 7 (MSS1). Thus, the production of inducible nitric oxide synthase, TNF- $\alpha$ and IL-1 $\beta$ are reduced (30). Chloroquine treatment, an autophagy inhibitor, inhibits the effect of rifampicin pretreatment on rotenone-stimulated IL-1 $\beta$ and IL-6 secretion. This indicates that rifampicin inhibits inflammation by modulating autophagy (31). In recent studies, various effects of rotenone have been shown on autophagy depending on the different dosages used and the cellular systems analyzed. In one study, rotenone reduced all autophagy but increased mitophagy in neurons (32), while in another study it was shown that rotenone increased autophagy and stimulated ROS induced autophagic cell death (33). 
Removal of damaged mitochondria is necessary to protect cells from ROS and pro-apoptotic molecules released by dysfunctional mitochondria. In a study, it was found that pre-treatment of rifampicin partially reduced mitochondrial membrane potential (MMP) induced by rotenone and partially reversed ROS production. Moreover, the protective effect of rifampicin on mitochondrial function is suppressed after the addition of the autophagy inhibitor. These results convince us that rifampicin leads to a reduction in ROS production through a tendency towards mitophagy (31).

\section{Rifampicin, a-Synuclein Aggregation, and SUMOylation}

a-Synuclein is the main protein component of Lewy Body in PD brains $(34,35)$ and is a protein of 140 amino acids. a-Synuclein aggregation is a critical step in the pathogenesis of PD. There is a strong association between a-synuclein upregulation and increased cytotoxicity and neurodegeneration (36). The aggregation of a-synuclein has been suggested to be one of the mechanisms linking mitochondrial dysfunction, another important pathway leading to PD pathogenesis (37).

Pathological forms of a-synuclein, which are spread in the parenchymal tissue of the brain, can contribute to the disease process by stimulating inflammatory-type reactions through microglial cells (38). In one study, by using pure microglial cell culture, the inflammatory potential of three different forms of a-synuclein was tested and TNF- $a$ and IL- 6 release as inflammation markers were examined (39). As a result, a fibril form of a-synuclein was found to be the most inflammatory form of protein. This result shows us that the inflammatory potential of a-synuclein is dependent on the aggregation state of the protein.

In another study, a-synuclein fibrils were reported to activate the THP-1 monocyte cell line and activate the release of IL-1 $\beta$ by TLR- 2 and NLRP3 activation (40). In another study, a-synuclein fibrils in microglial BV-2 cell culture were shown to be more effective in increasing the production and release of proinflammatory cytokines than in monomeric and oligomeric species (41). In previous studies, it has been shown that rifampicin can increase neuronal survival by inhibiting the inflammatory process induced by LPS-activated microglial cells $(10,28)$. Recent studies have shown that posttranslational modification by the small ubiquitin-like modifier called SUMOylation regulates mitochondrial dynamics. This mechanism is accepted to be one of the underlying mechanisms of PD $(42,43)$. Some of the proteins encoded by the genes involved in genetic changes in PD are regulated by SUMO.

Covalent binding of SUMO protein to the lysine residue of the target protein is an important control process in eukaryotic cells and regulates the function of hundreds of proteins in many different pathways. SUMOylation causes different results depending on the pathway in which it is located, but the basic principle is to change the interactions between substrate proteins for the molecule and between molecules (protein or DNA). Thus, it regulates the activities, localization, and stability of the substrates $(44,45)$. SUMO also affects cytoplasmic and membrane proteins, including ion channels and receptors (46-48), so that SUMOylation not only acts in the nucleus but also in different cellular processes including cell signaling, plasma membrane depolarization and signal transduction $(45,49)$.

SUMOylation of proteins has been shown to play an important role in synaptic transmission, plasticity and neuron conservation (50). Decreasing solubility and pathological accumulation of specific disease-related proteins such as a-synuclein is a common feature among neurodegenerative diseases such as PD. Cytoplasmic filamentous inclusions, whose main component is a-synuclein (51), are abundant in the neurons of PD patients that exhibit other important pathological features. In PD brains and Lewy Body disease (LB) with dementia, SUMO-1 is located in the outer part of LB, which is colocalized by a-synuclein (52). a-synuclein is a SUMO target and SUMOylation occurs on 2 lysine residues K96 and K102 on the protein, this was confirmed by transgenic mice expressing His6-tagged SUMO-2 (53). Reduced a-synuclein SUMOylation by mutation of SUMO-modified lysines, has been found to increase a-synuclein aggregation and toxicity in heterogeneous cells and in dopaminergic neurons of substantial nigra in PD rat models (53).

In a different study, the relationship between rifampicin and SUMOlation was evaluated. It was reported that rotenone-stimulated PC12 cells were prevented from increased apoptosis by increasing the SUMOylation of a-synuclein by pretreatment of rifampicin. In this study, pretreatment of rifampicin caused an early increase in SUMOylation, thereby increasing the solubility of a-synuclein, aggregates-prone neurodegeneration-related proteins. Subsequent treatment of rotenone-stimulated cells with rifampicin resulted in less formation of damaged and misfolded a-synucleins. However, the late generation of SUMOylation in cells has been found to cause a more difficulties in the reversal of toxicity from a-synuclein accumulation (54).

\section{Rifampicin (Rif) and its Oxidated Product (RifQ)}

Although many studies have shown the anti-inflammatory effects of rifampicin, there have been only a few studies performed using the oxidative product of rifampicin. It was found that when rifampicin was dissolved in aqueous solution, as a result of the spontaneous oxidation reaction, different oxidized species are produced - such as the rifampicin quinone (RifQ). This molecule differs from rifampicin in that the naphthyl core structure is converted into a naphthoquinone (Figure 1). This confers to the molecule's distinctive biochemical properties.

Rifampicin is defined as a potential immunosuppressive agent in rats, but these effects were obtained only with stocked solutions of the antibiotic, not with freshly prepared solutions. Therefore, the anti-inflammatory effects of rifampicin are attributed to the oxidant product RifQ of rifampicin (55). In addition, other studies have indicated that the oxidation product of rifampicin inhibits a-synuclein fibrillation and strengthens the disaggregation of formed fibrils (56). 
Rifampicin and its oxidized derivative, RifQ, have been shown to inhibit the activation of primary microglial cells induced by a-synuclein fibrils, which are inflammatory factors in PD (39, 57). RifQ has been shown to have the potential to inhibit neurotoxic effects induced by microglial cells activated by a-synuclein fibrils.

\section{CONCLUSION}

Numerous in vivo and in vitro studies suggest that rifampicin may have therapeutic effects in PD treatment. These results suggest that rifampicin may slow down the process by reducing oxidative stress, inhibiting inflammation, inhibiting the formation of a-synuclein aggregates, and separating the resulting aggregates and providing neuronal protection. Thus, rifampicin may be a novel method of therapy in the treatment of PD and may be used in the treatment of neurodegenerative diseases which have similar mechanisms.

Peer-review: Externally peer-reviewed.

Author Contributions: Concept - I.Y., E.E.A.; Supervision - I.Y., E.E.A.; Materials - I.Y., E.E.A.; Data Collection and/or Processing - I.Y., E.E.A.; Analysis and/or Interpretation - I.Y., E.E.A.; Literature Search - I.Y., E.E.A.; Writing - İ.Y., E.E.A.; Critical Reviews - I.Y., E.E.A.

Conflict of Interest: The authors have no conflict of interest to declare.

Financial Disclosure: The authors declared that this study has received no financial support.

Hakem Değerlendirmesi: Dış bağımsız.

Yazar Katkıları: Fikir - I.Y., E.E.A.; Denetleme - I.Y., E.E.A.; Gereçler - I.Y., E.E.A.; Veri Toplanması ve/veya İşlemesi - İ.Y., E.E.A.; Analiz ve/veya Yorum - I.Y., E.E.A.; Literatür Taraması - I.Y., E.E.A.; Yazan - I.Y., E.E.A.; Eleştirel İnceleme - I.Y., E.E.A.

Çıkar Çatışması: Yazarlar çıkar çatışması bildirmemişlerdir.

Finansal Destek: Yazarlar bu çalışmada finansal destek almadıklarını beyan etmişlerdir.

\section{REFERENCES}

1. Ambrosi G, Cerri S, Blandini F. A further update on the role of excitotoxicity in the pathogenesis of Parkinson's disease. J Neural Transm 2014; 121: 849-59. [CrossRef]

2. Giráldez-Pérez R, Antolín-Vallespín M, Muñoz M, Sánchez-Capelo A. Models of a-synuclein aggregation in Parkinson's disease. Acta Neuropathol Commun 2014; 2: 176. doi: 10.1186/s40478-0140176-9. [CrossRef]

3. Blesa J, Trigo-Damas I, Quiroga-Varela A and Jackson-Lewis V R. Oxidative stress and Parkinson's disease. Front Neuroanat 2015; 9: https://doi.org/10.3389/fnana.2015.00091 [CrossRef]

4. Franco-lborra S, Vila M, Perier C. The Parkinson disease mitochondrial hypothesis: where are we at? Neuroscientist 2016; 22: 26677. [CrossRef]
5. Vivekanantham S, Shah S, Dewji R, Dewji A, Khatri C, Ologunde R. Neuroinflammation in Parkinson's disease: role in neurodegeneration and tissue repair. Int J Neurosci 2015; 125: 717-25. [CrossRef]

6. Guerra de Souza AC, Prediger RD, Cimarosti H. SUMO-regulated mitochondrial function in Parkinson's disease. J Neurochem 2016; 137: 673-86. [CrossRef]

7. Bi W, Zhu L, Jing X, Zeng Z, Liang $Y, X u$ A, et al. Rifampicin improves neuronal apoptosis in LPS-stimulated co-cultured BV2 cells through inhibition of the TLR-4 pathway. Mol Med Rep 2014; 10: 1793-9. [CrossRef]

8. Jing $X$, Shi $Q, B i$ W, Zeng $Z$, Liang $Y$, Wu X, et al. Rifampicin protects PC12 cells from rotenone-induced cytotoxicity by activating GRP78 via PERK-elF2alpha-ATF4 pathway. PLoS One 2014; 9: doi: 10.1371/journal.pone.0092110.[CrossRef]

9. Xu J, Wei C, Xu C, Bennett M C, Zhang G, Li F, et al. Rifampicin protects PC12 cells against MPP+-induced apoptosis and inhibits the expression of an alpha-synuclein multimer. Brain Res 2007; 1139: 220-5. [CrossRef]

10. Bi W, Zhu L, Wang C, Liang Y, Liu J, Shi Q, et al. Rifampicin inhibits microglial inflammation and improves neuron survival against inflammation. Brain Res 2011; 1395: 12-20. [CrossRef]

11. Greenamyre JT, Betarbet R, Sherer TB. The rotenone model of Parkinson's disease: genes, environment, and mitochondria. Parkinsonism Relat Disord 2003; 9 (Suppl 2): S59-S64. [CrossRef]

12. Testa CM, Sherer TB, Greenamyre JT. Rotenone induces oxidative stress and dopaminergic neuron damage in organotypic substantia nigra cultures. Brain Res Mol Brain Res 2005; 134: 220-5. [CrossRef]

13. Watanabe $Y$, Himeda T, Araki T. Mechanisms of MPTP toxicity and their implications for therapy of Parkinson's disease. Med Sci Monit 2005; 11: 17-23.

14. Sherer TB, Betarbet R, Stout AK, Lund S, Baptista M, Panov AV, Cookson MR, Greenamyre JT. An in vitro model of Parkinson's disease: linking mitochondrial impairment to altered alpha-synuclein metabolism and oxidative damage. J Neurosci 2002; 22: 700615. [CrossRef]

15. Starkov AA. The role of mitochondria in reactive oxygen species metabolism and signaling. Ann N Y Acad Sci 2008; 1147: 37-52. [CrossRef]

16. Tretter L, Sipos I, Adam-Vizi V. Initiation of neuronal damage by complex I deficiency and oxidative stress in Parkinson's disease. Neurochem Res 2004; 29: 569-77. [CrossRef]

17. Zhu J, Chu CT. Mitochondrial dysfunction in Parkinson's disease. J Alzheimers Dis 2010; 20 (Suppl 2): S325-S34. [CrossRef]

18. Tobo'n-Velasco JC, Carmona-Aparicio L, Ali SF, Santamarı'a A. Biomarkers of cell damage induced by oxidative stress in Parkinson's disease and related models. Cent Nerv Syst Agents Med Chem 2010; 10: 278-86. [CrossRef]

19. Fariss MW, Chan CB, Patel M, Van Houten B, Orrenius S. Role of mitochondria in toxic oxidative stress. Mol Interv 2005; 5: 94-111. [CrossRef]

20. Beal MF. Does impairment of energy metabolism result in excitotoxic neuronal death in neurodegenerative illnesses? Ann Neurol 1992; 31: 119-30. [CrossRef]

21. Adams JD Jr, Chang ML, Klaidman L. Parkinson's disease-redox mechanisms. Curr Med Chem 2001; 8: 809-14. [CrossRef]

22. Steele MA, Burk RF, DesPrez RM. Toxic hepatitis with isoniazid and rifampin. A meta-analysis. Chest 1991; 99: 465-71. [CrossRef]

23. Xu B, Tang X, Chen J, Wu H, Chen W, Chen L. Rifampicin induces clathrin-dependent endocytosis and ubiquitin-proteasome degradation of MRP2 via oxidative stress-activated PKC-ERK/JNK/p38 and PI3K signaling pathways in HepG2 cells. Acta Pharmacol Sin 2019; doi: 10.1038/s41401-019-0266-0. [CrossRef] 
24. Oida $Y$, Kitaichi $K$, Nakayama $H$, Ito $Y$, Fujimoto $Y$, Shimazawa $M$, Nagai $\mathrm{H}$, Hara H. Rifampicin attenuates the MPTP-induced neurotoxicity in mouse brain. Brain Res 2006; 1082: 196- 204. [CrossRef]

25. Bo"ttcher T, Gerber J, Wellmer A, Smirnov AV, Fakhrjanali F, Mix E, et al. Rifampin reduces production of reactive oxygen species of cerebrospinal fluid phagocytes and hippocampal neuronal apoptosis in experimental Streptococcus pneumoniae meningitis. J Infect Dis 2000; 181: 2095-8. [CrossRef]

26. Chen S, Sun Y, Zeng Z, Tao E. Rifampicin inhibits apoptosis in rotenone-induced differentiated PC12 cells by ameliorating mitochondrial oxidative stress. Neural Regen Res 2010; 5: 251-6.

27. Zhang J, Culp ML, Craver JG, Darley-Usmar V. Mitochondrial function and autophagy: integrating proteotoxic, redox, and metabolic stress in Parkinson's disease. J Neurochem. 2018; 144: 691-709. [CrossRef]

28. Bi W, Zhu L, Jing X, Zeng Z, Liang $Y, X u$ A, et al. Rifampicin improves neuronal apoptosis in LPS-stimulated cocultured BV2 cells through inhibition of the TLR-4 pathway. Mol Med Rep 2014; 10 : 1793-9. [CrossRef]

29. Yang S, Xia C, Li S, Du L, Zhang L, Zhou R. Defective mitophagy driven by dysregulation of rheb and KIF5B contributes to mitochondrial reactive oxygen species (ROS)-induced nod-like receptor 3 (NLRP3) dependent proinflammatory response and aggravates lipotoxicity. Redox Biol 2014; 3: 63-71. [CrossRef]

30. Bi W, Jing $X$, Zhu L, Liang Y, Liu J, Yang L, et al. Inhibition of $26 \mathrm{~S}$ protease regulatory subunit 7 (MSS1) suppresses neuroinflammation. PLoS One 2012; 7: doi: 10.1371/journal.pone.0036142. [CrossRef]

31. Liang $Y$, Zhou T, Chen $Y$, Lin D, Jing X, Peng S, et al. Rifampicin inhibits rotenone-induced microglial inflammation via enhancement of autophagy. Neurotoxicology 2017; 63: 137-45. [CrossRef]

32. Giordano S, Dodson M, Ravi S, Redmann M, Ouyang X, Darley Usmar VM, et al. Bioenergetic adaptation in response to autophagy regulators during rotenone exposure. J Neurochem 2014; 131: 625-33. [CrossRef]

33. Chen Y, McMillan-Ward E, Kong J, Israels SJ, Gibson SB. Mitochondrial electron-transport-chain inhibitors of complexes I and II induce autophagic cell death mediated by reactive oxygen species. J Cell Sci 2007; 120: 4155-66. [CrossRef]

34. Forno LS. Neuropathology of Parkinson's disease. J Neuropathol Exp Neurol 1996; 55: 259-72. [CrossRef]

35. Martin FL, Williamson SJ, Paleologou KE, Allsop D, El-Agnaf OM. Alpha-synuclein and the pathogenesis of Parkinson's disease. Protein Pept Lett 2004; 11: 229-37. [CrossRef]

36. Bennett MC. The role of alpha-synuclein in neurodegenerative diseases. Pharmacol Ther 2005; 105: 311-31. [CrossRef]

37. Lee SJ. alpha-Synuclein aggregation: a link between mitochondrial defects and Parkinson's disease? Antioxid Redox Signal 2003; 3: 337-48. [CrossRef]

38. Couch Y, Alvarez-Erviti L, Sibson NR, Wood MJA, Anthony DC. The acute inflammatory response to intranigral-synuclein differs significantly from intranigral lipopolysaccharide and is exacerbated by peripheral inflammation. J Neuroinflamm 2011; 8: doi: 10.1186/1742-2094-8-166. [CrossRef]

39. Acuña L, Hamadat S, Corbalán NS, González-Lizárraga F, Dos-Santos-Pereira M, Rocca J, et al. Rifampicin and Its Derivative Rifam- picin Quinone Reduce Microglial Inflammatory Responses and Neurodegeneration Induced In Vitro by a-Synuclein Fibrillary Aggregates. Cells 2019; 8: doi: 10.3390/cells8080776. [CrossRef]

40. Gustot A, Gallea, Jl, Sarroukh R, Celej MS, Ruysschaert J-M, Raussens V. Amyloid fibrils are the molecular trigger of inflammation in Parkinson's disease. Biochem J 2015; 471: 323-33. [CrossRef]

41. Hoffmann A, Ettle B, Bruno A, Kulinich A, Hoffmann AC, von Wittgenstein J, et al. Alpha-synuclein activates BV2 microglia dependent on its aggregation state. Biochem Biophys Res Commun 2016; 479: 881-6. [CrossRef]

42. Gareau JR, Lima CD. The SUMO pathway: emerging mechanisms that shape specificity, conjugation, and recognition. Nat Rev Mol Cell Biol 2010; 11: 861-71. [CrossRef]

43. Eckermann K. SUMO and Parkinson's Disease. NeuroMolecular Med 2013; 15: 737-59. [CrossRef]

44. Dohmen RJ. SUMO protein modification. Biochim. Biophys. Acta 2004; 1695, 113-131. [CrossRef]

45. Hay RT. SUMO: a history of modification. Mol Cell 2005; 18: 1-12. [CrossRef]

46. Silveirinha V, Stephens GJ, Cimarosti H. Molecular targets underlying SUMO-mediated neuroprotection in brain ischemia. J Neurochem 2013; 127: 580-91. [CrossRef]

47. Wilkinson KA, Nakamura Y, Henley JM. Targets and consequences of protein SUMOylation in neurons. Brain Res Rev 2010; 64: 195212. [CrossRef]

48. Luo J, Ashikaga E, Rubin PP, Heimann MJ, Hildick KL, Bishop P, et al. Receptor trafficking and the regulation of synaptic plasticity by SUMO. Neuromolecular Med 2013; 15: 692-706. [CrossRef]

49. Anckar J, Sistonen L. SUMO: getting it on. Biochem Soc Trans 2007; 35: 1409-13. [CrossRef]

50. Henley JM, Craig TJ and Wilkinson KA. Neuronal SUMOylation: mechanisms, physiology, and roles in neuronal dysfunction. Physiol Rev 2014; 94: 1249-85. [CrossRef]

51. Spillantini MG, Schmidt ML, Lee VM, Trojanowski JQ, Jakes $R$, Goedert M. Alpha-synuclein in Lewy bodies. Nature 1997; 388: 839-40. [CrossRef]

52. Kim YM, Jang WH, Quezado MM, Oh Y, Chung KC, Junn E, et al. Proteasome inhibition induces a-synuclein SUMOylation and aggregate formation. J Neurol Sci 2011; 307: 157-61. [CrossRef]

53. Krumova $P$, Meulmeester E, Garrido M, Tirard M, Hsiao HH, Bossis $\mathrm{G}$, et al. Sumoylation inhibits a-synuclein aggregation and toxicity. J Cell Biol 2011; 194: 49-60. [CrossRef]

54. Lin D, Jing $X$, Chen $Y$, Liang $Y$, Lei $M$, Peng $S$, et al. Rifampicin pre-treatment inhibits the toxicity of rotenone-induced $P C 12$ cells by enhancing sumoylation modification of a-synuclein. Biochem Biophys Res Commun 2017; 485: 23-9. [CrossRef]

55. Konrad P, Stenberg P. Rifampicin quinone is an immunosuppressant, but not rifampicin itself. Clin Immunol Immunopathol 1988; 46: 162-6. [CrossRef]

56. Li J, Zhu M, Rajamani S, Uversky VN, Fink AL. Rifampicin inhibits alpha-synuclein fibrillation and disaggregates fibrils. Chem Biol 2004; 11: 1513-21. [CrossRef]

57. Bi W, Zhu L, Jing X, Liang Y, Tao E. Rifampicin and Parkinson's disease. Neurol Sci 2013; 34: 137-41. [CrossRef] 